\title{
RELATIONSHIP ISSUE BETWEEN BUDGETING AND MANAGEMENT ACCOUNTING
}

\section{Anastasiia Koliesnichenko ${ }^{1}$}

\section{DOI: https://doi.org/10.30525/978-9934-588-11-2_67}

At present the development of business processes of the competitive environment causes the urgent need for objective estimation of incomes and expenses not only at the end of a certain time interval, but also before its beginning. The distribution of activity spheres in the national economy has also raised an increased interest in the methods of identifying all reserves of the enterprise development during the planning stage of the production program. The main goal of the economic entities is to open and use these reserves, including the ways related to the development of such management practices as budgeting.

The solution of budgetary problems affects a number of important areas. Firstly, it concerns the problem of increasing competition among enterprises, which is due to the need to obtain additional competitive advantages, for instance, through more effective financial management. Secondly, each enterprise needs to find internal reserves to reduce production costs, justify optimal spending levels, and the need to optimize taxation. Thirdly, the importance of increasing the investment attractiveness of the company is growing. The essence of this aspect is that investors are more likely to finance enterprises with a high level of management organization.

The high interest in the issue of forming the budgeting system within the framework of management accounting is connected, basically with the improvement of the management system. In this regard, the questions of the theory and methodology of a new vision of management accounting techniques attract the attention of both practitioners and well-known scientists of this research area.

The peculiarities of the use of budgeting tools were investigated in the works of domestic and foreign authors. A great contribution to the development of management accounting, including budgeting techniques, has been made by such researchers as: V.V. Burtsev [1], N.V. Ruzhanskaya [6], T.P. Karpova [2], V.E. Khrutsky, D.M. Korkuna [3], O.G. Melnyk [4], V.F. Paliy, A.D. Sheremet, etc.

Among foreign authors published worldwide in this field it must be noted the works of R. Anthony, K. Drury, R. Mann [5], E. Mayer [5], M. Meskon, R. Shank, J. Shim, J. Riggs etc. However, a set of issues related to the peculiarities of the use of budgeting and management accounting techniques, their relationships remain open for discussion.

The strengthening of external and domestic competition caused by the introduction of domestic products into international markets has predetermined the need for deep changes in the management mechanism, which, in turn, can not be realized without increasing the control function of accounting and a real reorientation of the existing accounting models toward the interests of managers.

\footnotetext{
${ }^{1}$ National Technical University «Kharkov Polytechnic Institute», Ukraine 
The monitoring of budget execution is a necessary procedure and is carried out by means of a fact-finding plan. In this case, as the practice shows, the source of the factual information analyzed can be the data of both accounting and operational accounting which is sometimes called management accounting.

A practical approach has often demonstrates that management accounting is defined as a kind of accounting, which in addition is a way to separate income and expenditure by type of product, counterparties, responsibility centers and other analysts.

Management accounting registers built in accordance with the principles of the budgeting system provide information on the actual performance of the budget. For instance, there are budgeting principles [6] based on the principles of accounting for various directions of economic activity and specific objects of accounting (figure).

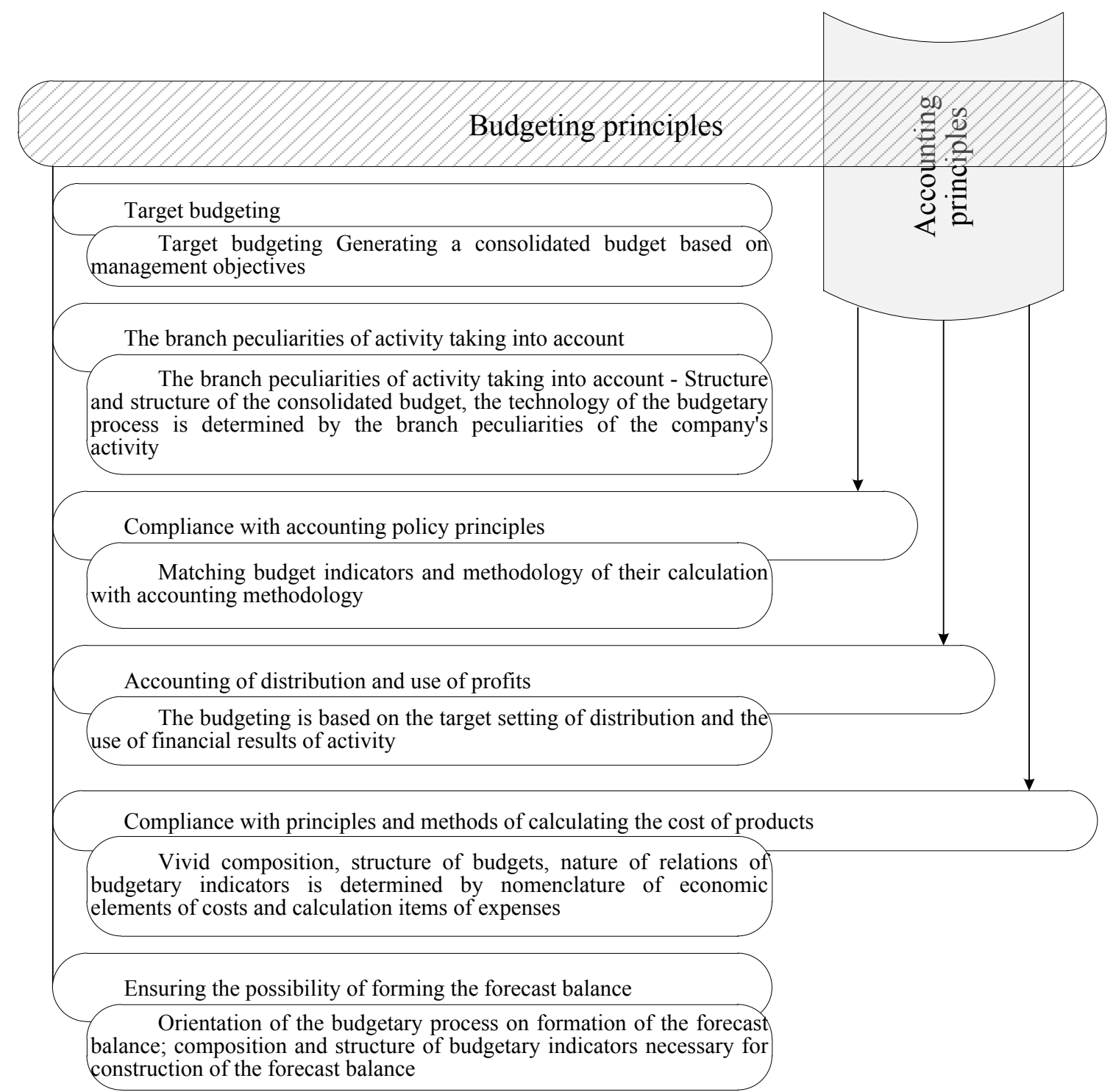

Figure. The principles of the budgeting system in accordance

Source:based on [6] 
At the same time, the creation of two parallel accounting systems is not always an effective solution. The most optimal option is to create a corporate management system, when the accounting and control system at the enterprise is unified, the chief accountant is responsible for the organization of all accounting and operational data are reflected in accounting.

However, some researchers also include into the creation of a plan system some significant aspects. There are the regulation of the process of harmonization and approval of management documentation in the company, the creation of an organizational structure and official instructions, etc. Based on this approach, budgeting can be interpreted as a necessary part of management accounting.

Thus, budgeting and management accounting processes are part of one whole mechanism aimed at realization of internal business processes in the enterprise with the purpose of achievement of the set goals of functioning and fulfillment of its mission. Effective management of the market subject in modern development conditions is heavily dependent on the quality and speed of use of these components.

\section{References:}

1. Burcev, V. V. (2006). Bjudzhetyrovanye v upravlenyy kommercheskoj orghanyzacyej [Budgeting in the management of a commercial organization]. Audytor, pp. 32-38.

2. Karpova, V. V. (2016). Indyvydualjnyye modely bjudzhetyrovanyja: konceptualjnyye podkhody i instrumenty postroenyja [Individual budgeting models: Conceptual approaches and building tools]. Accounting. Analysis. Audit, pp. 42-49.

3. Korkuna, D. M. (2009). Bjudzhetuvannja u systemi finansovogho planuvannja pidpryjemstva [Budgeting at the system of the financial planning department]. Lviv: Ivan Franko National University of Lviv, Vol. 19, pp. 330-334.

4. Meljnyk, O. Gh. (2004). Bjudzhetuvannja v systemi upravlinnja pidpryjemstvom : avtoreferat dys. kand.ekon.nauk, spec. 08.06.01 [Budgetary control system]. Ljviv.: Nac. un-t «Ljvivsjkapolitekhnika», 21 p.

5. Mann, R., Mayer, E. (1995). Kontrolyngh dlja nachynajushhykh [Controlling for beginners]. M.: Fynansy i statystyka, $304 \mathrm{p}$.

6. Ruzhanskaja, N. V. (2006). Bjudzhetyrovanye kak faktor sovershenstvovanyya korporatyvnogho upravlenyya $\mathrm{v}$ kompanyyi [The Budgeting as a factor for improving corporate governance in the company]. Vestn. SyktGhU. URL: http://koet.syktsu.ru/vestnik/2006/2006-1/5.htm 